KENOSIS : JURNAL KAJIAN TEOLOGI

ISSN 2460-6901(Print), 2656-4483 (Online)

https://e-journal.iaknambon.ac.id/index.php/KNS

DOI: 10.37196/kenosis.v1i1.191

\title{
MANAJEMEN BADAN PENGURUS DALAM MENINGKATKAN KOMPETENSI GURU PAR GMIT BENYAMIN OEBUFU
}

\section{Jusuf Elpontus Tanaem dan Imelda Marina Djira}

\author{
Institut Agama Kristen Negeri Kupang \\ Jalan Cak Doko No. 76, Kampung Baru, Kupang - 85112, \\ Nusa Tenggara Timur \\ yusuftanaem86@gmail.com
}

\begin{abstract}
This study aims to analyze the strategies implemented by the governing body in improving the competence of the GMIT Benjamin Oebufu Child and Adolescent Service teachers to provide directions for achieving service goals and to anticipate changes that will occur at the change of service periods. This study uses a descriptive method with qualitative approach. This research was conducted at GMIT Benjamin oebufu, Klasis East Kupang City. The subjects in this study were five people consisting of the management body and the service supporting unit. The data collection techniques used in this study were interview, observation and documentation. The data analysis technique used is the Analysis Interactive which is divided into four parts, namely data collection, data reduction, data presentation and conclusion / verification. The results showed that the strategy of the governing body in increasing the competence of GMIT Benjamin Oebufu's CAS teachers was discussion of teaching materials, Bible study, training, seminars and comparative studies. The advantages obtained from increasing the competence of CAS teachers are better understanding of God's Word, creative in teaching, helping service preparation, improving the quality of teaching and children get better understanding the teaching delivered. Internal constraints in increasing the competence of CAS teachers are the difficulty in managingtime for work, school and services. The external obstacle is the limited operational costs for activities.
\end{abstract}

Keywords: Strategy, Governing body, Competence improvement, CAS Teachers, Sunday's School

\begin{abstract}
Abstrak
Penelitian ini bertujuan menganalisis strategi yang dilakukan badan pengurus dalam meningkatkan kompetensi guru Pelayanan Anak dan Remaja Gereja Masehi Injili di Timor (GMIT) Benyamin Oebufu untuk memberikan arah pencapaian tujuan pelayanan serta mengantisipasi perubahan yang akan terjadi pada saat pergantian periode pelayanan.
\end{abstract}


Penelitian ini menggunakan metode deskriptif dengan pendekatan kualitatif. Penelitian ini dilaksanakan di GMIT Benyamin Oebufu Klasis Kota Kupang Timur dengan subyek dalam penelitian ini berjumlah 5 orang yang terdiri dari badan pengurus dan unit pembantu pelayanan. Teknik pengumpulan data yang digunakan dalam penelitian ini adalah wawancara dan observasi dan dokumentasi. Teknik analisis data yang digunakan adalah Analysis Interactive yang terbagi menjadi 4 bagian yaitu pengumpulan data, reduksi data, penyajian data serta penarikan kesimpulan/verifikasi. Hasil penelitian menunjukkan bahwa strategi badan pengurus dalam meningkatkan kompetensi guru PAR GMIT Benyamin Oebufu adalah pembahasan materi ajar, pendalaman Alkitab, pelatihan, seminar dan studi banding. Keuntungan yang diperoleh dari peningkatan kompetensi guru PAR adalah lebih memahami firman Tuhan, kreatif dalam pengajaran, membantu persiapan pelayanan, kualitas pengajaran meningkat dan anak lebih memahami pengajaran yang disampaikan. Kendala internal dalam peningkatan kompetensi guru PAR yaitu kesulitan pembagian waktu antara pekerjaan, sekolah dengan pelayanan. Kendala eksternalnya yaitu terbatasnya biaya operasional kegiatan.

Kata Kunci: Strategi, Badan pengurus, Peningkatan kompetensi, Guru PAR, Sekolah minggu.

\section{PENDAHULUAN}

Upaya peningkatan kualitas Sumber Daya Manusia (SDM) merupakan hal yang harus dilakukan agar dapat terwujudnya tujuan pembangunan nasional. ${ }^{1}$ Bidang pendidikan menjadi aspek utama dalam upaya pengembangan SDM karena menekankan pengembangan pengetahuan, sikap dan keterampilan manusia. Melalui pendidikan yang baik, diharapkan dapat diperoleh SDM yang menguasai ilmu pengetahuan dan teknologi serta memiliki perilaku yang positif. Penguasaan ilmu pengetahuan dan teknologi akan meningkatkan kualitas manusia sebagai subyek pembangunan.

Untuk meningkatkan kualitas pendidikan, kualitas guru harus ditingkatkan terlebih dahulu dengan meningkatkan kompetensinya. ${ }^{2}$ Dapat diasumsikan bahwa semakin baik kompetensi yang dimiliki seorang guru maka semakin baik pula kualitas pengajarannya dan semakin meningkatkan pula kualitas pendidikan. Kualitas seorang guru terlihat ketika dia mengajar di depan kelas dan melaksanakan tugas lain yang dipercayakan kepadanya.

Seorang guru harus memiliki kompetensi karena dia berkewajiban mencerdaskan anak bangsa secara fisik maupun emosional. ${ }^{3}$ Menjadi seorang guru memang tidak mudah. Dengan kata lain, tidak semua orang bisa menjadi guru. Pekerjaan ini tidak bisa dikerjakan oleh mereka yang tidak memiliki keahlian atau 
kompetensi seorang guru. ${ }^{4}$ Keahlian atau kompetensi tidak datang begitu saja, namun ada proses yang harus dilalui berupa pendidikan maupun latihan secara terus menerus. Seorang calon guru biasanya harus menempuh pendidikan di Lembaga Pendidik Tenaga Kependidikan (LPTK) tertentu. Selain itu mereka juga mengikuti sejumlah pelatihan untuk mengembangkan kompetensinya.

Upaya ini tidak bisa dilakukan oleh lembaga pendidikan saja tetapi harus didukung oleh semua elemen bangsa. Gereja sebagai bagian dari bangsa ini juga memiliki tanggung jawab untuk mengembangkan SDM, khususnya melalui kegiatankegiatan rohani maupun pengembangan pendidikan Kristen. Mengembangkan pendidikan yang baik adalah salah satu panggilan gereja (Amanat Agung Tuhan). ${ }^{5}$ Upaya ini terjadi berbagai kategori pelayanan, salah satunya kategorial Pelayanan Anak dan Remaja (PAR) atau yang sebelumnya dikenal dengan sekolah minggu, yaitu pendidikan non formal yang diselenggarakan oleh Gereja Protestan dan hanya diberikan pada minggu. ${ }^{6}$ PAR atau sekolah minggu pendidikan non formal tentang Alkitab yang dilaksanakan setiap hari Minggu serta diberikan bagi anak dan remaja yang berusia sampai 15 tahun.

Pelayanan Anak dan Remaja dilayani oleh guru PAR yang memiliki kualifikasi pendidikan yang beragam. Seorang guru sekolah minggu (PAR) memiliki tugas atau kewajiban untuk mengajar, menggembalakan, memberikan teladan, menginjili dan mendoakan anak-anak. ${ }^{7}$ Dengan tugas atau kewajiban ini, guru PAR harus dipersiapkan sebelumnya agar mampu melaksanakan tugasnya dengan baik.

Seseorang bisa menjadi guru PAR hanya karena panggilan atau kerinduan untuk melayani tanpa ada ketentuan kualifikasi pendidikan. Dengan demikian gereja melalui badan pengurus PAR memiliki tanggung jawab untuk meningkatkan kompetensi guru PAR. Kompetensi yang harus dimiliki seorang guru sekolah minggu (PAR) ada 4 yaitu, dia adalah orang yang sudah dilahirkan kembali (lahir baru), memiliki karakter dan kepribadian Kristus, totalitas dalam pelayanan anak serta memiliki pengetahuan akan kebenaran Alkitab. ${ }^{8}$

Seseorang yang dilahirkan kembali (Yohanes 3:3-6) merupakan suatu kehidupan baru sebagai hasil hubungan yang menyatu antara manusia dengan Allah di dalam Yesus Kristus. Hal ini memungkinkan orang yang lahir baru tersebut memiliki karakter dan kepribadian Kristus serta memiliki pengetahuan akan Firman Tuhan. 
Pengenalan akan Allah dan hidup bergaul dengan Allah membuat Allah menyingkapkan diri-Nya sehingga manusia bisa mengenal Allah lebih dalam.

Keempat kompetensi guru PAR tersebut harus terus ditingkatkan agar pembelajaran juga terus berkembang. Proses peningkatan kompetensi ini tidak hanya dilakukan secara mandiri tetapi juga dilaksanakan secara bersama-sama dalam kelompok-kelompok. Pembinaan guru PAR untuk meningkatkan kompetensi dapat dilaksanakan badan pengurus agar pengajaran dan pelayanan kepada anak pun semakin meningkat.

Penelitian yang dilakukan di Kabupaten Jember tentang upaya peningkatan kompetensi profesional guru menunjukkan bahwa upayanya termasuk dalam kategori tinggi. ${ }^{9}$ Penelitian ini menggunakan metode kuantitatif dengan menghitung presentasi dari masing-masing indikator. Penelitian ini hanya mengkaji kompetensi profesional dengan mengabaikan kompetensi pedagogik, kompetensi kepribadian dan kompetensi sosial padahal keempat kompetensi ini saling berkaitan dan tidak terpisahkan satu dengan yang lain.

Penelitian lain dilakukan di SMKN 1 Blitar tentang manajemen kompetensi guru dalam meningkatkan daya saing menunjukkan bahwa pengembangan kompetensi guru dilakukan melalui Diklat, On the job training, dan Musyawarah Guru Mata Pelajaran (MGMP). ${ }^{10}$ Penelitian ini menggunakan metode pendekatan kualitatif dengan metode studi kasus. Kelebihan penelitian ini adalah melakukan perencanaan peningkatan kompetensi guru melalui analisis kebutuhan, melakukan Evaluasi diri sekolah (EDS) kemudian menetapkan program dan jadwal peningkatan kompetensi guru.

Penelitian lain juga dilakukan di SMA Negeri 1 Banjarsari tentang peran kepala sekolah dalam meningkatkan kompetensi guru. ${ }^{11}$ Penelitian ini merupakan penelitian deskriptif dengan pendekatan kualitatif. Hasil penelitiannya mendeskripsikan upaya peningkatan kompetensi guru berdasarkan tupoksi kepala sekolah yang hanya bersifat internal tanpa upaya melibatkan pihak-pihak dari luar sekolah.

Ketiga penelitian di atas memang dilakukan di lembaga pendidikan formal (sekolah) bukan di lembaga pendidikan informal. Belum ada penelitian sejenis yang dilakukan di pendidikan informal ataupun sekolah minggu. Oleh karena itu artikel ini 
menggunakan penelitian di lembaga pendidikan formal sebagai acuan penelitian terdahulu dalam pemecahan masalah yang sedang diteliti.

Jemaat Benyamin Oebufu sebagai bagian dari Gereja Masehi Injili di Timor (GMIT) Klasis Kota Kupang Timur melaksanakan ibadah Pelayanan Anak dan Remaja (PAR) setiap hari Minggu. Ibadah PAR dipimpin oleh guru PAR yang dikoordinir oleh Badan Pengurus (BP) dan Unit Pembantu Pelayanan (UPP) PAR Benyamin Oebufu. Pada periode 2019 - 2023, BP PAR Benyamin Oebufu memiliki 45 orang guru PAR yang didominasi oleh guru yang berlatar pendidikan SMA sebanyak 29 orang.

Tabel 1. Kualifikasi Akademik guru PAR GMIT Benyamin Oebufu

\begin{tabular}{|l|c|c|}
\hline NO & KUALIFIKASI AKADEMIK & JUMLAH \\
\hline 1 & SMA / Sederajat & 29 orang \\
\hline 2 & Diploma 2 dan 3 & 1 orang \\
\hline 3 & Strata 1 & 13 orang \\
\hline 4 & Strata 2 & 2 orang \\
\hline & JUMLAH & 45 orang \\
\hline
\end{tabular}

Sumber : BP PAR GMIT Benyamin Oebufu, 2020

Dari tabel di atas dapat dilihat bahwa guru PAR GMIT Benyamin Oebufu didominasi oleh yang berlatar pendidikan SMA sebanyak 29 orang sedangkan S1 dan S2 hanya 15 orang. Memang belum ada ketentuan yang jelas tentang kualifikasi akademik guru PAR. Namun jika mengacu pada Peraturan Menteri Pendidikan Nasional Republik Indonesia Nomor 16 tahun 2007 tentang standar kualifikasi akademik dan kompetensi guru, mewajibkan semua guru memiliki kualifikasi akademik minimal D-IV atau S1. ${ }^{12}$ Dengan demikian, perlu adanya upaya dari badan pengurus untuk meningkatkan kompetensi guru PAR GMIT Benyamin Oebufu.

Penelitian ini difokuskan pada strategi peningkatan kompetensi pelayan gereja khususnya guru sekolah minggu. Penelitian ini bertujuan menganalisis strategi yang dilakukan badan pengurus dalam meningkatkan kompetensi guru PAR GMIT Benyamin Oebufu. Strategi peningkatan kompetensi yang sudah ada dan sudah 
digunakan dianalisis untuk memberikan arah pencapaian tujuan pelayanan serta mengantisipasi perubahan yang akan terjadi pada saat pergantian periode pelayanan.

\section{METODE PENELITIAN}

Penelitian ini menggunakan metode deskriptif dengan pendekatan kualitatif, yaitu menggambarkan secara sistmatis, faktual dan akurat mengenai fakta, sifat dan hubungan yang diselidiki. ${ }^{13}$ Metode deskriptif digunakan sesuai dengan tujuan penelitian yaitu menganalisis manajemen strategi badan pengurus dalam meningkatkan kompetensi guru PAR GMIT Benyamin Oebufu. Penelitian ini dilaksanakan di GMIT Benyamin Oebufu, Klasis Kota Kupang Timur dengan subyek dalam penelitian ini berjumlah 5 orang yang terdiri dari BP dan UPP PAR. Teknik pengumpulan data yang digunakan dalam penelitian ini yaitu wawancara dan observasi dan dokumentasi. Wawancara dilakukan untuk menggali sejumlah informasi tentang strategi badan pengurus dalam meningkatkan kompetensi guru PAR. sementara itu, observasi dilakukan untuk mengamati secara langsung upaya tersebut serta dokumentasi dilakukan untuk mempelajari dokumen-dokumen yang terkait dengan penelitian. Teknik analisis yang digunakan adalah Analysis Interactive, ${ }^{14}$ yang terbagi menjadi 4 bagian yaitu pengumpulan data, reduksi data, penyajian data dan penarikan kesimpulan/verifikasi.

\section{HASIL DAN PEMBAHASAN}

Sesuai Keputusan Persidangan Majelis Sinode GMIT nomor 10 tahun 2018 tentang Peraturan Pembentukan Dan Tata Hubungan Badan Pelayanan, Badan Pembantu Pelayanan, Dan Unit Pembantu Pelayanan pasal 23 poin 4 bahwa jabatan pelayanan hanya 4 tahun dalam 1 periode pelayanan. ${ }^{15}$ Hal ini membawa dampak pada pelayanan PAR GMIT Benyamin Oebufu. Setiap 4 tahun terjadi perubahan badan pengurus dan anggota PAR GMIT Benyamin Oebufu. Ada anggota baru dan ada guru PAR yang kembali melayani. Oleh karena itu dilakukan penyamaan tujuan atau persepsi pelayanan guru PAR. Selain itu, tingkat pendidikan juga beragam sehingga BP PAR melakukan beberapa kegiatan atau strategi untuk meningkatkan kompetensi gurunya. 
Strategi ini ada yang dilakukan di dalam jemaat maupun di luar jemaat. Strategi-strategi tersebut adalah: Pertama, pembahasan materi ajar. Setiap hari Minggu setelah mengajar (melayani) anak-anak, guru-guru sekolah minggu selalu berkumpul untuk melakukan pembahasan atau persiapan mengajar (melayani) di minggu berikutnya. Dalam pembahasan ini, guru-guru membahas hal-hal teologis yang akan diajarkan dan saling berbagi pengetahuan teologi tentang isi Alkitab serta membicarakan hal-hal teknis tentang pembelajaran. Pembahasan materi ajar ini bertujuan bukan saja untuk persiapan mengajar, tetapi juga dapat meningkatkan pemahaman guru PAR tentang isi Alkitab.

Kedua, pendalaman Alkitab. Pendalaman Alkitab guru PAR dilaksanakan sebulan sekali dalam bentuk ibadah. Pembicara atau pemateri dalam Pendalaman Alkitab ini biasanya pendeta atau mereka yang punya latar belakang teologi. Alkitab menjadi napas bagi pendidikan dan pelayanan Kristen sehingga perlu dipahami secara mendalam. Proses pemahaman Alkitab bisa dilakukan sendiri maupun dipelajari bersama orang lain. Guru PAR harus secara mandiri mempelajari Alkitab dan secara bersama-sama membahas firman Tuhan dengan orang lain sehingga dia mengetahui dan memahami bagian Alkitab yang diajarkan kepada anak.

Strategi ketiga yaitu pelatihan. Guru PAR juga ikut dalam pelatihan-pelatihan yang diselenggarakan oleh beberapa organisasi seperti Superbook Indonesia. Dengan mengikuti pelatihan diharapkan guru PAR mendapat pengetahuan dan keterampilan untuk diterapkan dalam pengajaran. Memang tidak semua guru PAR diikutkan dalam pelatihan tetapi mereka yang ikut bertanggungjawab membagikan ilmu dan pengalaman yang didapat kepada teman-teman yang lain. Keterampilan dan kompetensi guru PAR akan diperbaiki dengan mengikuti pelatihan.

Keempat, Guru PAR juga mengikuti seminar-seminar yang berhubungan dengan pelayanan anak seperti yang diselenggarakan oleh Lembaga Pelayanan Anak NTT. Dengan mengikuti seminar akan meningkatkan pengetahuan dan keterampilan guru PAR. Sekarang ini (masa pandemi COVID-19) sudah banyak dilaksanakan seminar-seminar online (webinar) sehingga mengurangi pengeluaran untuk biaya seminar. Guru PAR yang mengikuti seminar membagikan pengetahuannya kepada teman-teman yang lain. 


\section{MANAJEMEN BADAN PENGURUS DALAM MENINGKATKAN KOMPETENSI GURU PAR GMIT BENYAMIN OEBUFU}

Strategi terakhir adalah studi banding, untuk melihat dan membandingkan pelayanan PAR Benyamin Oebufu dengan gereja lain. Guru PAR Benyamin Oebufu pernah melaksanakan studi banding ke kota Malang. Tujuan dilaksanakannya studi banding adalah memperoleh sejumlah pengetahuan dan keterampilan dari tempat yang dikunjungi untuk diterapkan di tempat asal. Tidak semua guru PAR diikutkan dalam studi banding mengingat jarak yang jauh dan biaya yang diperlukan cukup banyak. Guru PAR yang mengikuti studi banding ketika pulang membagikan pengetahuan dan keterampilan yang diperoleh dari Malang.

Berdasarkan hasil penelitian, keuntungan yang didapatkan dari mengikuti kegiatan-kegiatan tersebut adalah: Pertama, guru PAR lebih memahami firman Tuhan. Semakin sering seseorang mempelajari sesuatu membuatnya memiliki pemahaman mendalam terhadap hal tersebut. Pemahaman mendalam terhadap firman Tuhan mempengaruhi pengajarannya semakin baik. Kompetensi pedagogi (pengetahuan, pemahaman) yang baik akan menghasilkan pembelajaran yang efektif. ${ }^{16}$ Pembelajaran yang efektif ditunjang oleh penguasaan materi pembelajaran secara luas.

Kedua, guru PAR lebih kreatif dalam pengajaran. Guru PAR yang sudah mengikuti kegiatan-kegiatan peningkatan kompetensi tersebut akan berdampak pada pengajarannya. Guru PAR akan lebih kreatif saat mengajar dan menggunakan media. Kreativitas guru sangat berpengaruh terhadap perkembangan anak-anak. Oleh karena itu guru harus dalam kreatif dalam menyampaikan materi sehingga anak-anak semakin mudah memahami pelajaran dan menjadikan anak-anak lebih kreatif pula dalam belajar. ${ }^{17}$ Kreativitas akan mempengaruhi kompetensi dan guru yang kompeten akan menciptakan lingkungan belajar yang efektif dan menyenangkan.

Ketiga, Membantu persiapan pelayanan. Guru PAR GMIT Benyamin Oebufu biasanya melaksanakan pembahasan materi ajar setiap hari Minggu setelah mengajar Sekolah Minggu hari itu. Pembahasan materi ajar ini bertujuan untuk mempersiapkan pelayanan minggu selanjutnya. Selain membahas materi yang akan disampaikan, guru PAR juga mempersiapkan alat peraga yang akan dipakai. Persiapan yang dilakukan guru sebelum mengajar meliputi persiapan tertulis (Rencana Pelaksanaan Pembelajaran), mental, situasi emosional yang akan dibangun serta lingkungan belajar yang produktif. ${ }^{18}$ Persiapan guru PAR GMIT Benyamin Oebufu dilaksanakan secara bersama-sama melalui pembahasan materi ajar. 
Keempat, kualitas pengajaran meningkat. Dengan pemahaman akan Firman Tuhan yang mendalam, persiapan mengajar yang baik serta pengajaran yang kreatif maka dapat diasumsikan bahwa kualitas pengajaran pun meningkat. Guru perlu mendapatkan bantuan dan binaan untuk meningkatkan kualitas mengajarnya yang meliputi kemampuan pedagogisnya maupun pengembangan sikap keprofesionalnya. ${ }^{19}$ Kemampuan pedagogis guru sekolah minggu berkaitan dengan penguasaan akan Firman Tuhan dan sikap profesional merupakan kemampuan melaksanakan tugas dengan baik. Peningkatan kualitas pengajaran akan diikuti dengan peningkatan hasil belajar anak.

Kelima, anak sekolah minggu lebih memahami pengajaran yang disampaikan. Ketika guru PAR memahami apa yang diajarkan serta mempersiapkan diri dengan baik maka pembelajaran akan berjalan secara efektif dan anak akan lebih memahami apa yang ia pelajari. Guru yang profesional itu tercermin pada keberhasilannya melaksanakan tugas mengajar yang ditandai dengan kemampuan dalam menguasai materi dan menyampaikannya. ${ }^{20}$ Semakin baik guru mengajar maka semakin baik pula pemahaman anak.

Namun pelaksanaan kegiatan-kegiatan tersebut kadang mengalami kendala yaitu:

1. Waktu

Strategi peningkatan kompetensi guru PAR ini terkendala waktu. Guru-guru PAR ada yang masih bersekolah, kuliah dan sudah bekerja. Penyesuaian antara waktu sekolah atau bekerja dengan pelayanan menjadi kendala dalam kegiatan dalam mengembangkan kompetensi.

2. Dana

Selain waktu, dana juga menjadi kendala dalam pengembangan kompetensi. Untuk mengikuti pelatihan, seminar dan studi banding membutuhkan biaya ikut dalam kegiatan tersebut. Sementara itu, anggaran yang disediakan gereja belum mengakomodasi semua kegiatan sehingga badan pengurus biasanya mengusahakan dana sendiri untuk mengakomodasi kegiatankegiatan yang tidak ada dalam program kerja PAR.

Sudah saatnya gereja memberikan perhatian serius terhadap tugas pendidikan Kristen karena warga gereja tidak hanya membutuhkan khotbah-khotbah dari mimbar 
tetapi juga pembinaan dan pendidikan Kristen. ${ }^{21}$ Sekolah minggu sebagai bagian dari pendidikan Kristen di gereja perlu mendapat perhatian serius sebagai dasar pendidikan warga gereja. Kompetensi dari guru sekolah minggu harus terus ditingkatkan sehingga pelayanan kepada anak menjadi lebih baik. Guru sekolah minggu pun memiliki tanggung jawab untuk meningkatkan kompetensinya secara mandiri. Seorang guru sekolah minggu tidak boleh berhenti belajar.

Anak sekolah minggu perlu dituntun agar mengalami perjumpaan pribadi dengan Yesus Kristus dan hidup bersama Roh Kudus. ${ }^{22}$ Perjumpaan ini membuka ruang bagi Roh Kudus berkarya dalam diri anak sehingga mengubah karakternya menyerupai Kristus. Konsep lahir baru yang disampaikan Yesus dalam percakapan dengan Nikodemus (Yoh 3:1-21) dapat terjadi jika ada perjumpaan secara khusus antara anak dengan Kristus. Agar bisa menuntun anak berjumpa dengan Kristus, guru sekolah minggu sudah harus mengalami perjumpaan itu sendiri. Dengan kata lain, guru sekolah minggu sudah harus lahir baru sebelum menuntun anak untuk lahir baru juga.

Oleh karena itu, upaya peningkatan kompetensi guru PAR pun harus dilaksanakan terus menerus. Terdapat 5 strategi badan pengurus dalam meningkatkan kompetensi guru PAR GMIT Benyamin Oebufu. Pertama, pembahasan materi ajar. Dalam melaksanakan pengajaran dan pembelajaran, guru harus mampu merencanakan dengan baik. ${ }^{23}$ Guru yang gagal merencanakan berarti merencanakan kegagalan. Oleh karena itu, guru PAR harus mempersiapkan dengan serius pembelajaran setiap minggunya.

Kedua, pendalaman Alkitab. Sebagai dasar pendidikan, ada banyak hal tentang pelaksanaan pendidikan Kristen dalam Alkitab yang perlu digali secara mendalam. ${ }^{24}$ Dalam Alkitab, Ezra bertekad untuk meneliti Taurat Tuhan dan melakukannya serta mengajar ketetapan dan peraturan di antara orang Israel (Ezra 7:10). Guru PAR perlu meneliti, mempelajari dan melakukan sebelum mengajarkan firman Tuhan kepada anak-anak. Dengan demikian, anak membutuhkan keteladanan dari guru PAR dalam mempelajari dan melakukan kebenaran Firman Tuhan.

Ketiga, pelatihan. Pelatihan bertujuan meningkatkan dan mengasah kemampuan (kompetensi) seseorang dalam mengerjakan tugas atau pekerjaan tertentu secara memuaskan. ${ }^{25}$ Pelatihan berkaitan dengan upaya memperbaiki keterampilan 
dan kemampuan praktis yang diperlukan guna melaksanakan pekerjaan secara efektif. ${ }^{26}$ Guru PAR perlu mengikuti pelatihan untuk memperbaiki keterampilan dan kompetensinya agar pengajarannya terlaksana dengan efektif.

Keempat, seminar. Seminar biasanya membahas suatu topik khusus di bawah bimbingan seorang ahli yang berkompeten di bidang tersebut. ${ }^{27}$ Pada masa pandemi Covid-19 sekarang ini, guru PAR bisa mengikuti seminar-seminar online (webinar) secara gratis yang diselenggarakan oleh berbagai lembaga pendidikan maupun gereja. Guru PAR bisa memilih topik-topik seminar yang relevan dengan pelayanannya.

Kelima, studi banding. Studi banding merupakan konsep belajar yang dilakukan di lokasi dan lingkungan berbeda untuk meningkatkan mutu, perbaikan sistem, penentuan kebijakan baru dan lain-lain. ${ }^{28}$ Studi banding dapat dilaksanakan dengan mengunjungi sekolah minggu yang dianggap sudah baik pelayanannya. Di tempat studi banding, guru PAR dapat menggali sejumlah informasi, dokumen maupun pelayanan yang dapat mengembangkan potensi dirinya, pengajaran maupun pelayanan di tempat asalnya. Memang studi banding membutuhkan biaya jika tempatnya berjauhan dan dalam jumlah yang banyak sehingga tidak perlu dilakukan sesering mungkin.

Dengan mengikuti kegiatan-kegiatan tersebut akan meningkatkan kompetensi dari guru PAR itu sendiri. Dampak dari peningkatan kompetensi ini adalah guru PAR lebih memahami Firman Tuhan, lebih kreatif dalam pengajaran, membantu guru PAR dalam persiapan pelayanan, kualitas pengajaran meningkat dan anak lebih memahami pelajaran yang disampaikan. Kualitas pembelajaran dipengaruhi oleh perencanaan materi pembelajaran, pelaksanaan pembelajaran dan penilaian hasil belajar sehingga membantu guru dalam mengajar dan membantu siswa dalam memahami pelajaran. ${ }^{29}$

Guru PAR juga harus selalu belajar untuk memperbaiki diri dan pengajarannya. Guru PAR dapat belajar dari pengalaman, mengevaluasi diri, rekan pelayanan, buku, internet, tulisan di majalah, dan seminar yang diadakan oleh berbagai lembaga pendidikan. ${ }^{30}$ Hal ini berarti bahwa guru PAR bisa belajar dari apa saja, siapa saja, kapan saja dan di mana saja, tidak dibatasi ruang dan waktu.

Upaya peningkatan kompetensi ini juga memiliki kendala. Untuk mengikuti kegiatan di internal jemaat, kendala yang dihadapi berupa kesulitan membagi waktu antara bekerja sekolah/kuliah dengan melayani. Pada waktu yang sudah disepakati 
untuk pelaksanaan kegiatan, ada guru PAR yang masih di tempat kerja atau di kampus. Sementara itu untuk kegiatan di luar jemaat, terbatasnya dana operasional kegiatan membuat badan pengurus tidak bisa mengikutsertakan semua guru PAR dalam kegiatan pengembangan kompetensi. Keadaan ini menuntut guru PAR untuk bisa mengembangkan kompetensinya secara mandiri sehingga kualitas pengajaran pun meningkat.

\section{KESIMPULAN}

Berdasarkan hasil pembahasan di atas disimpulkan bahwa strategi badan pengurus dalam meningkatkan kompetensi guru PAR GMIT Benyamin Oebufu yaitu pembahasan materi ajar, pendalaman Alkitab, ikut serta dalam pelatihan, seminar dan studi banding. Keuntungan yang didapat dari strategi tersebut adalah guru PAR lebih memahami firman Tuhan dan kreatif dalam pengajaran, membantu persiapan pelayanan, kualitas pengajaran meningkat dan anak lebih memahami pelajaran yang disampaikan. Kendala yang dialami badan pengurus dalam strategi secara internal yaitu terbatasnya waktu karena guru PAR memiliki pekerjaan dan terbatasnya dana yang dimiliki. Secara eksternal, kendala yang dihadapi yaitu terbatasnya dana operasional kegiatan.

\section{Endnotes:}

\footnotetext{
${ }^{1}$ Aida Nirwana, Murniati, and Yusrizal, "Strategi Kepala Sekolah Dalam Meningkatkan Kompetensi Profesional Guru Pada SD Negeri 2 Kota Banda Aceh," Jurnal Administrasi Pendidikan 3, no. 4 (2015): 34-43, https://doi.org/10.22373/jid.v14i2.505.

${ }^{2}$ Brigitta Putri Atika Tyagita and Ade Iriani, "Strategi Peningkatan Kompetensi Pedagogik Guru Untuk Meningkatkan Mutu Sekolah," Kelola: Jurnal Manajemen Pendidikan 5, no. 2 (2018): 165-76, https://doi.org/10.24246/j.jk.2018.v5.i2.p165-176.

${ }^{3}$ I Gusti Ayu Sri Juniantari, "Pentingnya Peningkatan Kompetensi Guru Dalam Pencapaian Hasil Belajar Siswa," Jurnal Ilmu Pendidikan 1, no. March (2017): 1-12.

${ }^{4}$ Rita Mariyana, "Kompetensi Guru Dalam Pembelajaran Berbasis Pendidikan Karakter Untuk Anak Usia Dini," PEDAGOGIA Jurnal Ilmu Pendidikan 12, no. 1 (2016): 1-18, https://doi.org/10.17509/pedagogia.v12i1.3296.

5 Japarlin Marbun, "Peranan Gereja Bagi Pendidikan Nasional," Jurnal Pendidikan Agama Kristen : Regula Fidei I, no. 1 (2016): 141-62.

6 Adriana Tfaentem, Ana Irhandayaningsih, and Amin Taufiq Kurniawan, "Motivasi Anak-Anak Sekolah Minggu Dalam Memanfaatkan Koleksi Di Perpustakaan GKI Peterongan Semarang," Jurnal Ilmu Perpustakaan 4, no. 2 (2015): 97-105.

${ }^{7}$ Marta Uli Nadapdap, "Pengaruh Profesionalisme Guru Sekolah Minggu Terhadap Pemahaman Materi Yang Diajarkan Pada Anak Usia 9-12 (Kelas Besar) Tahun Di GBI Taman," REGULA VIDEI : Jurnal Pendidikan Agama Kristen 1, no. 2 (2016): 306-27.
} 
${ }^{8}$ Tanto Kristiono and Deo Putra Perdana, "Hambatan Dan Pelayanan Guru Sekolah Minggu Di Gereja Kristen Jawa Jebres Surakarta,” Jurnal Teologi Gracia Deo 1, no. 2 (2019): 90-100.

${ }^{9}$ Fahrudi Ahwan Ikhsan et al., "Upaya Peningkatan Kompetesi Profesionalisme Guru Ips Di Kabupaten Jember," JURNAL PENDIDIKAN EKONOMI: Jurnal Ilmiah Ilmu Pendidikan, Ilmu Ekonomi Dan Ilmu Sosial 11, no. 2 (2017): 14-23, https://doi.org/10.19184/jpe.v11i2.5833.

${ }^{10}$ Muh Hambali and M Luthfi, "Manajemen Kompetensi Guru Dalam Meningkatkan Daya Saing," Journal of Management in Education (JMIE) 2, no. 1 (2017): 10-19.

${ }^{11}$ Emas Kurnianingsih, "Peran Kepala Sekolah Dalam Meningkatkan Kompetensi Guru," IJEMAR: Indonesian Journal of Education Management \& Administration Review 1, no. 2 (2017): 11-18, https://doi.org/10.30762/ed.v1i2.449.

12 Kementerian Pendidikan RI, "Peraturan Menteri Pendidikan Nasional Nomor 16 Tahun 2007 Tentang Standar Kualifikasi Akademik Dan Kompetensi Guru,” 2007, 1-31.

13 Yusuf Tanaem and Imelda Djira, "STRATEGI PEMBELAJARAN PENDIDIKAN AGAMA KRISTEN DI PUSAT PENGEMBANGAN ANAK IO-0497 BENYAMIN OEBUFU," VISIO DEI : Jurnal Teologi Kristen 2, no. 2 (2020): 180-202, https://doi.org/10.35909/visiodei.v2i2.96.

${ }^{14}$ Ilyas, "Pendidikan Karakter Melalui Homeschooling," Journal of Nonformal Education 2, no. 1 (2016): 91-98, https://doi.org/10.15294/jne.v2i1.5316.

15 Majelis Sinode GMIT, "Peraturan Pembentukan Dan Tata Hubungan Badan Pelayanan, Badan Pembantu Pelayanan, Dan Unit Pembantu Pelayanan," Keputusan Persidangan Majelis Sinode GMIT Nomor : 10/KEP/PMS-GMIT/XLII/2018, 2018, 88-135.

16 Taufiq Eka Riandhana, "Pengaruh Kompetensi Pedagogik Dan Kompetensi Profesional Guru Terhadap Pembelajaran IPS Di SMP Negeri Kota Palu,” Jurnal Katalogis 4, no. 1 (2016): 178-88.

${ }^{17}$ Monawati and Fauzi, "Hubungan Kreativitas Mengajar Guru Dengan Prestasi Belajar Siswa," Jurnal Pesona Dasar 6, no. 2 (2018): 33-43, https://doi.org/10.24815/pear.v6i2.12195.

${ }_{18}$ Juniriang Zendrato, "Tingkat Penerapan Rencana Pelaksanaan Pembelajaran Di Kelas Suatu Studi Kasus Di SMA Dian Harapan Jakarta," Scholaria: Jurnal Pendidikan Dan Kebudayaan 6, no. 2 (2016): 58-73, https://doi.org/10.24246/j.scholaria.2016.v6.i2.p58-73.

${ }^{19}$ Hadi, "Peningkatan Kualitas Mengajar Guru Melalui Supervisi Klinis Oleh Pengawas Sekolah Di Sekolah Dasar," JMKSP (Jurnal Manajemen, Kepemimpinan, Dan Supervisi Pendidikan) 1, no. 1 (2016): 74-79.

20 Zakiya and Nurhafizah, "Pengembangan Keprofesian Berkelanjutan Dalam Meningkatkan Profesionalisme Guru Pendidikan Anak Usia Dini," Jurnal Obsesi : Jurnal Pendidikan Anak Usia Dini 3, no. 2 (2019): 356-65, https://doi.org/10.31004/obsesi.v3i2.196.

${ }^{21}$ Johanes Waldes Hasugian, "Kurikulum Dan Pembelajaran Warga Jemaat Dewasa Di Gereja," KURIOS (Jurnal Teologi Dan Pendidikan Agama Kristen) 5, no. 1 (2019): 36-53.

${ }^{22}$ Binsen S Sidjabat, "Penguatan Guru PAK Untuk Pendidikan Karakter: Melihat Kontribusi Seri Selamat," Evangelikal: Jurnal Teologi Injili Dan Pembinaan Warga Jemaat 3, no. 1 (2019): 30-48.

${ }^{23}$ Hardisem Syabrus, "Kesiapan Dalam Pelaksanaan Proses Belajar Mengajar Sekolah Menengah Kejuruan Di Kota Pekanbaru,” Pekbis 7, no. 3 (2015): 24-30.

${ }^{24}$ Maria Lidya Wenas and I Putu Ayub Darmawan, "Signifikansi Pendidikan Anak Dalam Perspektif Alkitab," Evangelikal: Jurnal Teologi Injili Dan Pembinaan Warga Jemaat 1, no. 2 (2017): 118, https://doi.org/10.46445/ejti.v1i2.69.

${ }^{25}$ Nurul Khurotin and Tri Wulida Afrianty, "Analisis Pelatihan Dan Pengembangan Sumber Daya Manusia Di PT Beon Intermedia Cabang Malang,” Jurnal Administrasi Bisnis 64, no. 1 (2018): 195203.

${ }^{26}$ Nurhayati Ali Hasan, "Pendidikan Dan Pelatihan Sebagai Upaya Peningkatan Kinerja Pustakawan," LIBRIA 10, no. 1 (2018): 95-115.

${ }^{27}$ Erikson Damanik, "Dampak Seminar Dan Workshop Accurate Terhadap Minat Belajar Software Akuntansi," Jurnal Tekinkom, 2017, 41-46.

28 Pengkuh Ibnu Sudana, "Studi Banding," Binus Univercity Quality Management Center, 2014, https://qmc.binus.ac.id/2014/10/28/pengertian-studi-banding/.

${ }^{29}$ Siti Mukroni, "Pengaruh Kualitas Pembelajaran Guru Ekonomi Terhadap Kepuasan Siswa Di SMA Negeri 2 Sentajo Raya,” Pekbis Jurnal 9, no. 2 (2017): 140-50.

${ }^{30}$ Binsen S. Sidjabat, Pendidikan Kristen Konteks Sekolah: 12 Pesan Untuk Guru Dan Pengelola Pendidikan, ed. Yosep Kurnia, Pertama (Bandung: Kalam Hidup, 2018). 


\section{DAFTAR PUSTAKA}

Damanik, Erikson. "Dampak Seminar Dan Workshop Accurate Terhadap Minat Belajar Software Akuntansi.” Jurnal Tekinkom, 2017, 41-46.

Hadi. "Peningkatan Kualitas Mengajar Guru Melalui Supervisi Klinis Oleh Pengawas Sekolah Di Sekolah Dasar.” JMKSP (Jurnal Manajemen, Kepemimpinan, Dan Supervisi Pendidikan) 1, no. 1 (2016): 74-79.

Hambali, Muh, and M Luthfi. "Manajemen Kompetensi Guru Dalam Meningkatkan Daya Saing." Journal of Management in Education (JMIE) 2, no. 1 (2017): $10-19$.

Hasan, Nurhayati Ali. "Pendidikan Dan Pelatihan Sebagai Upaya Peningkatan Kinerja Pustakawan.” LIBRIA 10, no. 1 (2018): 95-115.

Hasugian, Johanes Waldes. "Kurikulum Dan Pembelajaran Warga Jemaat Dewasa Di Gereja.” KURIOS (Jurnal Teologi Dan Pendidikan Agama Kristen) 5, no. 1 (2019): 36-53.

Ikhsan, Fahrudi Ahwan, Fahmi Arif Kurniawan, Bejo Apriyanto, and Elan Artono Nurdin. "Upaya Peningkatan Kompetesi Profesionalisme Guru Ips Di Kabupaten Jember.” JURNAL PENDIDIKAN EKONOMI: Jurnal Ilmiah Ilmu Pendidikan, Ilmu Ekonomi Dan Ilmu Sosial 11, no. 2 (2017): 14-23. https://doi.org/10.19184/jpe.v11i2.5833.

Ilyas. "Pendidikan Karakter Melalui Homeschooling." Journal of Nonformal Education 2, no. 1 (2016): 91-98. https://doi.org/10.15294/jne.v2i1.5316.

Juniantari, I Gusti Ayu Sri. "Pentingnya Peningkatan Kompetensi Guru Dalam Pencapaian Hasil Belajar Siswa.” Jurnal Ilmu Pendidikan 1, no. March (2017): $1-12$.

Kementerian Pendidikan RI. "Peraturan Menteri Pendidikan Nasional Nomor 16 Tahun 2007 Tentang Standar Kualifikasi Akademik Dan Kompetensi Guru," 2007, 1-31.

Khurotin, Nurul, and Tri Wulida Afrianty. "Analisis Pelatihan Dan Pengembangan Sumber Daya Manusia Di PT Beon Intermedia Cabang Malang.” Jurnal 
Administrasi Bisnis 64, no. 1 (2018): 195-203.

Kristiono, Tanto, and Deo Putra Perdana. "Hambatan Dan Pelayanan Guru Sekolah Minggu Di Gereja Kristen Jawa Jebres Surakarta.” Jurnal Teologi Gracia Deo 1, no. 2 (2019): 90-100.

Kurnianingsih, Emas. "Peran Kepala Sekolah Dalam Meningkatkan Kompetensi Guru." IJEMAR: Indonesian Journal of Education Management \& Administration Review 1, no. 2 (2017): 11-18. https://doi.org/10.30762/ed.v1i2.449.

Majelis Sinode GMIT. "Peraturan Pembentukan Dan Tata Hubungan Badan Pelayanan, Badan Pembantu Pelayanan, Dan Unit Pembantu Pelayanan.” Keputusan Persidangan Majelis Sinode GMIT Nomor:10/KEP/PMSGMIT/XLII/2018, 2018, 88-135.

Marbun, Japarlin. "Peranan Gereja Bagi Pendidikan Nasional.” Jurnal Pendidikan Agama Kristen : Regula Fidei I, no. 1 (2016): 141-62.

Mariyana, Rita. "Kompetensi Guru Dalam Pembelajaran Berbasis Pendidikan Karakter Untuk Anak Usia Dini.” PEDAGOGIA Jurnal Ilmu Pendidikan 12, no. 1 (2016): 1-18. https://doi.org/10.17509/pedagogia.v12i1.3296.

Monawati, and Fauzi. "Hubungan Kreativitas Mengajar Guru Dengan Prestasi Belajar Siswa." Jurnal Pesona Dasar 6, no. 2 (2018): 33-43. https://doi.org/10.24815/pear.v6i2.12195.

Mukroni, Siti. "Pengaruh Kualitas Pembelajaran Guru Ekonomi Terhadap Kepuasan Siswa Di SMA Negeri 2 Sentajo Raya.” Pekbis Jurnal 9, no. 2 (2017): 140-50.

Nadapdap, Marta Uli. "Pengaruh Profesionalisme Guru Sekolah Minggu Terhadap Pemahaman Materi Yang Diajarkan Pada Anak Usia 9-12 (Kelas Besar) Tahun Di GBI Taman.” REGULA VIDEI : Jurnal Pendidikan Agama Kristen 1, no. 2 (2016): 306-27.

Nirwana, Aida, Murniati, and Yusrizal. "Strategi Kepala Sekolah Dalam Meningkatkan Kompetensi Profesional Guru Pada SD Negeri 2 Kota Banda Aceh." Jurnal Administrasi Pendidikan 3, no. 4 (2015): 34-43. https://doi.org/10.22373/jid.v14i2.505.

Riandhana, Taufiq Eka. "Pengaruh Kompetensi Pedagogik Dan Kompetensi 
Profesional Guru Terhadap Pembelajaran IPS Di SMP Negeri Kota Palu.” Jurnal Katalogis 4, no. 1 (2016): 178-88.

Sidjabat, Binsen S. Pendidikan Kristen Konteks Sekolah: 12 Pesan Untuk Guru Dan Pengelola Pendidikan. Edited by Yosep Kurnia. Pertama. Bandung: Kalam Hidup, 2018.

Sidjabat, Binsen S. "Penguatan Guru PAK Untuk Pendidikan Karakter: Melihat Kontribusi Seri Selamat.” Evangelikal: Jurnal Teologi Injili Dan Pembinaan Warga Jemaat 3, no. 1 (2019): 30-48.

Sudana, Pengkuh Ibnu. "Studi Banding.” Binus Univercity Quality Management Center, 2014. https://qmc.binus.ac.id/2014/10/28/pengertian-studi-banding/.

Syabrus, Hardisem. "Kesiapan Dalam Pelaksanaan Proses Belajar Mengajar Sekolah Menengah Kejuruan Di Kota Pekanbaru.” Pekbis 7, no. 3 (2015): 24-30.

Tanaem, Yusuf, and Imelda Djira. "STRATEGI PEMBELAJARAN PENDIDIKAN AGAMA KRISTEN DI PUSAT PENGEMBANGAN ANAK IO-0497 BENYAMIN OEBUFU." VISIO DEI : Jurnal Teologi Kristen 2, no. 2 (2020): 180-202. https://doi.org/10.35909/visiodei.v2i2.96.

Tfaentem, Adriana, Ana Irhandayaningsih, and Amin Taufiq Kurniawan. "Motivasi Anak-Anak Sekolah Minggu Dalam Memanfaatkan Koleksi Di Perpustakaan GKI Peterongan Semarang.” Jurnal Ilmu Perpustakaan 4, no. 2 (2015): 97105.

Tyagita, Brigitta Putri Atika, and Ade Iriani. "Strategi Peningkatan Kompetensi Pedagogik Guru Untuk Meningkatkan Mutu Sekolah.” Kelola: Jurnal Manajemen Pendidikan 5, no. 2 (2018): 165-76. https://doi.org/10.24246/j.jk.2018.v5.i2.p165-176.

Wenas, Maria Lidya, and I Putu Ayub Darmawan. "Signifikansi Pendidikan Anak Dalam Perspektif Alkitab.” Evangelikal: Jurnal Teologi Injili Dan Pembinaan Warga Jemaat 1, no. 2 (2017): 118. https://doi.org/10.46445/ejti.v1i2.69.

Zakiya, and Nurhafizah. "Pengembangan Keprofesian Berkelanjutan Dalam Meningkatkan Profesionalisme Guru Pendidikan Anak Usia Dini.” Jurnal Obsesi: Jurnal Pendidikan Anak Usia Dini 3, no. 2 (2019): 356-65. https://doi.org/10.31004/obsesi.v3i2.196. 
Zendrato, Juniriang. "Tingkat Penerapan Rencana Pelaksanaan Pembelajaran Di Kelas Suatu Studi Kasus Di SMA Dian Harapan Jakarta." Scholaria: Jurnal Pendidikan Dan Kebudayaan 6, no. 2 (2016): 58-73. https://doi.org/10.24246/j.scholaria.2016.v6.i2.p58-73. 